Canadian University Music Review

Revue de musique des universités canadiennes

\title{
Iain Fenlon, ed. The Renaissance: From the 1470s to the End of the 16th Century. Music and Society. Englewood Cliffs, N.J.: Prentice Hall, 1989. x, 418 pp. ISBN 0-13-773409-3 (hardcover), ISBN 0-13-036161-5 (softcover)
}

\section{Terry D. Brown}

Volume 16, numéro 2, 1996

URI : https://id.erudit.org/iderudit/1014430ar

DOI : https://doi.org/10.7202/1014430ar

Aller au sommaire du numéro

Éditeur(s)

Canadian University Music Society / Société de musique des universités canadiennes

ISSN

0710-0353 (imprimé)

2291-2436 (numérique)

Découvrir la revue

Citer ce compte rendu

Brown, T. D. (1996). Compte rendu de [Iain Fenlon, ed. The Renaissance: From the 1470s to the End of the 16th Century. Music and Society. Englewood Cliffs,

N.J.: Prentice Hall, 1989. x, 418 pp. ISBN 0-13-773409-3 (hardcover), ISBN

0-13-036161-5 (softcover)]. Canadian University Music Review / Revue de

musique des universités canadiennes, 16(2), 118-120.

https://doi.org/10.7202/1014430ar

All Rights Reserved (C Canadian University Music Society / Société de musique des universités canadiennes, 1996
Ce document est protégé par la loi sur le droit d'auteur. L'utilisation des services d’Érudit (y compris la reproduction) est assujettie à sa politique d'utilisation que vous pouvez consulter en ligne.

https://apropos.erudit.org/fr/usagers/politique-dutilisation/ 


\section{REVIEWS/COMPTES RENDUS}

\section{Introduction to Man and Music/Music and Society Series, Part II}

We continue with the series of reviews devoted to the volumes of the Man and Music/Music and Society series (general editor, Stanley Sadie) that was begun in the previous volume of this journal. As noted at that time, the books are a supplement to the television programmes called "Man and Music," which were produced by Granada TV in the United Kingdom in the mid-1980s. The publication of the books has followed in random order, and the series has only recently been completed.

During the past ten years there have been significant changes in the way that musicologists approach the study of music, as well as significant gains made in our knowledge of early repertoires. As will be seen below, reviewers report that some of the earlier volumes now appear dated, and already need revision. Furthermore, I am pleased that several of our reviewers have questioned the lack of specific Canadian content in the series. We have a musical heritage of which we can be proud; it should be recognized by those outside of this country.

Paul F. Rice

Iain Fenlon, ed. The Renaissance: From the 1470s to the End of the 16th Century. Music and Society. Englewood Cliffs, N.J.: Prentice Hall, 1989. x, 418 pp. ISBN 0-13-773409-3 (hardcover), ISBN 0-13-036161-5 (softcover).

1. Iain Fenlon, "Music and Society"; 2. Christopher Reynolds, "Rome: a City of Rich Contrast"; 3. Iain Fenlon, "Venice: Theatre of the World"; 4. William F. Prizer, "North Italian Courts, 1460-1540"; 5. Allan W. Atlas, "Aragonese Naples"; 6. Richard Freedman, "Paris and the French Court under François I"; 7. Frank Dobbins, "Lyons: Commercial and Cultural Metropolis"; 8. Martin Picker, "The Habsburg Courts in the Netherlands and Austria, 1477-1530"; 9. James Haar, "Munich at the Time of Orlande de Lassus"; 10. Robin A. Leaver, "The Lutheran Reformation"; 11. Susan Gattuso, "16th-Century Nuremberg"; 12. Craig Monson, "Elizabethan London"; 13. Tess Knighton, "The Spanish Court of Ferdinand and Isabella"; 14. Kristine K. Forney, "16th-Century Antwerp."

A review at this time of a book published in 1989 might more honestly call itself a retrospective. This is especially true given the rapid evolution of the societally-oriented "New Musicology" over the past few years. ${ }^{1}$ A number of

1 For a discussion of this phenomenon, see Ellen Rosand, "The Musicology of the Present," AMS Newsletter 25, no. 1 (1995): 10-11, 15. 
important monographs and collections of essays have appeared in the preceding half-decade which show signs of forming a new mainstream of musical criticism. Few of these, however, have much to do with the Renaissance. The most obvious exception is Gary Tomlinson's Music in Renaissance Magic, ${ }^{2}$ where Ficino meets Foucault. Its author aims as much to alter modern discourse about music as to puzzle out an older discourse, and to do so in the light of an analysis of difference. What would musicologists have made ten years ago of all of this "discourse" and "difference," or indeed of Tomlinson's subtitle, Toward a Historiography of Others? An interdisciplinary volume with NewMusicological leanings is The Crannied Wall: Women, Religion, and the Arts in Early Modern Europe, edited by Craig Monson, whose excellent chapter in the work at hand outlines the social uses of music at the English court. ${ }^{3}$

As for The Renaissance from the 1470s to the End of the 16th Century, it cannot really be said even to foreshadow the critical developments of the 1990s. It does nonetheless provide a fine summary of what the "old musicology" managed to learn about a select group of places and the people who caused music to occur in them, which is saying quite a lot. Editor Iain Fenlon, in his Introduction, stresses that the reader will not be faced with compositional techniques, a sequence of masterpieces, or an aggregation of biographies (p. 1), and this is true; although a number of biographies do emerge, they are more often those of exceptional musical patrons than of musicians. These sections, dealing with Isabella d'Este, Margaret of Austria, Elizabeth of England, and others, are both interesting and valuable, because they demonstrate how the tastes and personalities of rulers shaped the surviving repertory. Unfortunately, they often tend to reinforce the popular definition of "society" as the rich and powerful. This is largely inevitable, one must admit, because it is the music of court and church which survives in written form.

Nonetheless, and regardless of the space given by several of the authors to the middle classes (largely in the context of printing), and to the lower classes (as usual, in the context of musicians themselves), even a glance at the list of chapter titles suggests that this is a book about the most powerful persons in the largest, most important cities. Several deal specifically with music at royal courts. We learn about the backgrounds of musicians (national more than socio-economic), their rates of pay, and the competition for their services. For instance, musicians at the English court tended to be the best-paid in the land, yet earned less than the king's barber (p. 317). There are a lot of data about salaries, but none of the authors pretends to theorize about the musical economy at all: the relative social and economic status of musicians, the economic impact of printing on musicians and society as a whole. For example, Richard Freeman discusses both printing and various cultural registers with regard to the chanson in France, without giving due consideration to the issue of class. In some cases authors lament the accession of a monarch with little time for music, which brought a great period of patronage to an end. Ought not a book

2Chicago and London: The University of Chicago Press, 1993.

3 Ann Arbor: University of Michigan Press, 1992. 
about "music and society" to consider that many in a declining kingdom (the parallels with our own time are telling) might have seen a large chapel as a squandering of resources? The same should be stressed in the case of Antwerp, where the manifestation of a new religious outlook - sadly, according to author Kristine K. Forney (p. 376)-slowed musical development. Sadly for whom, besides twentieth-century musicologists? Was it really the purpose or duty of sixteenth-century European society to go on providing us with big manuscripts and prints of big sacred music? Instead of objectively examining the reformations of the late Renaissance period to understand how they reflect contemporary societal values, we decry them as anti-musical. Surely this reflects the biases of musicians and scholars who regret the perceived modern decline of musical standards, or more interestingly, the faltering of the private and governmental agencies of patronage which have underwritten the musical activities they enjoy, not to mention their university educations.

It is perhaps no coincidence that the essay which best succeeds in connecting social forces with matters of musical style and developments is not about a royal court. Susan Gattuso begins her study of Nuremberg by pointing out that the city-almost alone among those discussed in this volume-was never a royal residence (p. 286), and then describes its class structure and economy. The facts, figures, and lists which follow are not the end in themselves, as is so often the case, but rather a means for showing that the tasteful musical societies of the upper classes were short-lived because they essentially provided a mere hobby, while the musically fossilized Meistersinger flourished for centuries by offering the middle classes an opportunity to follow a code and tradition, to rise through the ranks and become masters, to attain a sense of achievement.

Inevitably, this book reflects the research concerns of the 1970s and 1980s: patronage, the size of chapels, musicians' careers, and so forth. It covers these well, but says little about nationality, less about class, and nothing about gender and identity, all of which are the concerns of the 1990s. Of course it would be wrong-headed to criticize a book simply for not having been written at a later date. Reviews which appeared at the volume's release are rightly positive. Jeffrey Dean called it "a splendid book" which represented great progress in achieving its goals. ${ }^{4}$ Those interested in a thoughtful discussion of how the book summarizes the "social-historical focus so characteristic of the AngloAmerican musicological endeavour of the 1970s and early 1980s" should consult Tim Carter's critique. 5 Among his several valid points are that the volume neglects the peripheral regions of Europe almost entirely, and perhaps ignores actual music too much, failing to demonstrate the music-society link at the level of style and individual works. Carter suggests that "it is precisely an exploration of the points of contact between the public and private worlds of music that will most likely produce 'a new kind of picture of music history' for the 1990s (p. 271)." Indeed.

Terry D. Brown

4 Early Music 19 (1991): 112-15.

5 Music and Letters 72 (1991): 268-71. The quotation, 268. 